\title{
INVESTIGATION OF SHEAR STRENGTH PARAMETERS AND EFFECT OF DIFFERENT COMPACTIVE EFFORT ON LATERITIC SOIL STABILIZED WITH COCONUT HUSK ASH AND LIME
}

\author{
C. C. Ikeagwuanii ${ }^{1}$, D. C. Nwonu ${ }^{2, *}$, C. Eze ${ }^{3}$ and I. Onuoha ${ }^{4}$ \\ 1,2,3,4 DePARTMENT OF Civil EnGineERING, University of NigERIA NSUKKA, ENUGU STATE NIGERIA \\ Email addresses:1chijioke.ikeagwuani@unn.edu.ng,2donald.chimobi@gmail.com, \\ 33ingsley.eze.178762@unn.edu.ng, ${ }^{4}$ ifeanyi.onuoha.175978@unn.edu.ng
}

\begin{abstract}
This paper presented the results of the shear strength parameters and compaction characteristics of lateritic soil stabilized with a combination of Lime and Coconut husk ash (CHA) in various percentages using two compaction methods namely; British standard heavy (BSH) and British standard light(BSL). Undrained triaxial test was conducted to determine shear strength parameters of the stabilized soil with confining pressures of $69 \mathrm{kN} / \mathrm{m}^{2}, 138 \mathrm{kN} / \mathrm{m}^{2}$ and $276 \mathrm{kN} / \mathrm{m}^{2}$, after preliminary tests had been carried out to determine index properties of the soil. The test was conducted on a mixture of natural soil with 4\%lime, which gave least plasticity index and percentages of CHA from 0 $12 \%$ by dry weight of soil. The BSL and BSH were applied on mixture of soil + 4\% lime + percentages of CHA ranging from 4-20\% by dry weight of soil. The most plausible improvement in maximum dry density was obtained by adding $4 \%$ lime $+12 \%$ CHA and 4\% lime $+16 \%$ CHA using BSH and BSL respectively. The results also show significant improvement in angle of internal friction and cohesion of the soil at $6 \%$ and $8 \%$ CHA addition respectively.
\end{abstract}

Keywords: Coconut husk ash; Compaction; Lateritic soil; Lime; Shear strength; Stabilization.

\section{INTRODUCTION}

The dwindling economic fortunes of most countries around the world particularly Nigeria has taken its toll greatly in the infrastructural development of the country. The construction industry is more often than not the most affected negatively due to its high involvement in the execution of most capital projects. The impact on the extremely scarce resources available for most construction works has been very devastating resulting in the attendant inflation in the cost of most conventional construction materials. The need therefore to evolve other relatively cheap but highly efficient alternative constructional materials cannot be fully overemphasized.

In the execution of construction projects on soils in most tropical countries such as Nigeria, the most naturally occurring and highly abundant soil is the lateritic soils. Laterite is a rock deposit principally of sedimentary origin which is known to form due to weathering, and is one of the most readily available raw materials for road construction in Nigeria [1]. Therefore, lateritic soils hold great potential with respect to offsetting the cost of construction projects.
Although in its natural state, the extent of its usefulness in geotechnical engineering application cannot be ascertained. This is as a result of the fact that in geotechnical design, variations prevalent in the natural soil deposit and its properties is among the greatest threats encountered [2]. This poses some great challenges in determining the actual behaviour of soils under the action of imposed load. Among the soil properties, it is the shear strength of the soil that determines the ability of the soil to transmit load to the layers beneath. Whereas the maximum dry density (MDD) achieved through compaction gives indication of the strength of the compacted soil [3].

\subsection{Shear Strength}

Shear strength of the soil can be seen as the magnitude of shear stress that will result in yielding of a soil mass under load and is believed to exist due to interaction of particles brought about by cohesive and frictional forces [4]. As such, the soil shear strength is measured in terms of cohesion and angle of internal friction of the soil particles. The shear strength of the soil is therefore likely to be affected by any action than can impact on

\footnotetext{
* Corresponding author, tel: +234-806-534-5122
} 
the cementation or interlocking of the soil particles [5]. Furthermore, it is known that strength properties of the soil are affected by soil composition, initial condition, loading condition and its structure [6]. Structure here would include factors like cementation and voids that can affect particle arrangement within the soil [6]. Hence, a method of improving the structure of the soil to augment its strength properties would be the use of admixtures to induce cementation of soil particles and filling of existing voids within the soil mass. Stabilizing agents like lime, etc are widely applied in soil stabilization to improve the soil properties.

\subsection{Compaction}

Compaction is a mechanical form of soil stabilization that is widely applied in executing construction projects. Compaction is very pertinent to soil stabilization and the MDD obtained through compaction is directly related to the strength of the compacted soil [3]. Furthermore, the soil type, addition of admixtures, compactive effort and moisture content affects the dry density of soil achieved by compaction [7].

\subsection{Brief Review}

Since the advent of soil stabilization technology, lime stabilization has been the most widely used for the stabilization of weak soils. However, due to its soaring cost implications, it is often added with other relatively cheap additives for soil stabilization. One of such additives is Coconut Husk Ash (CHA), a product of combustion of coconut husk, which is a major agricultural waste from tropical regions. CHA has proved to be very efficient in soil stabilization because of its siliceous, aluminous and iron oxide content [8]. The combination of lime and CHA as stabilizing agents in this research work was to offset the cost required for lime stabilization. In recent times, some researchers have worked on combination of different stabilizing agents for the stabilization of lateritic soil. Two researchers [9] worked on combination of stabilizing agents in which they used coconut shell, leaf and husk for stabilization of lateritic soil. Their result showed that the combination of coconut shell, leaf and husk ash improved the strength properties of the soil. Three researchers [8], recently worked on the compressibility characteristics of lateritic soil stabilized with a combination of lime and CHA. They discovered that a combination of $4 \%$ lime and $5 \%$ coconut husk ash improved the compressibility characteristics of the natural soil. Some other researchers [10] [11], have also worked on the stabilization of poor lateritic soil with CHA. They discovered that the addition of CHA greatly improved the geotechnical properties of the soil. Furthermore, it has been asserted by [4] that the fines content of lateritic soil has a significant effect on its shear strength parameters, having done a research work which showed that an increase in fines content reduces and increases the angle of internal friction and cohesion of the soil respectively.

Based on the works of the aforementioned researchers, a combination of fine particles of CHA and lime could have a significant effect on the shear strength parameters and compaction characteristics of the natural lateritic soil. Hence, this research work is an investigation to determine the shear strength parameters and effect of different compactive effort on lateritic soil stabilized with a combination of coconut husk ash and lime. This work therefore aims to determine the combination that will produce the maximum cohesion, angle of friction and optimum MDD for the stabilized soil.

\section{MATERIALS}

\subsection{Soil Sample}

The lateritic soil used for this work was obtained from a borrow pit of about $2 \mathrm{~m}$ depth in a single location at about 1 kilometer from the green house gate of the University of Nigeria Nsukka in Enugu state. Nsukka is said to lie at latitude of $6^{\circ} 51^{\prime} 24^{\prime \prime} \mathrm{N}$ and longitude of $7^{\circ} 23^{\prime} 45^{\prime \prime} \mathrm{E}$ according to the geographical map of Nigeria [12]. The soil was dug out of the borrow pit with the aid of a shovel and this can be described as a disturbed sampling method. The sample was collected and sealed in polyethene bags to prevent ingress of moisture that can change the moisture content of the natural soil. The collected soil sample was taken to the soil mechanics laboratory section of the Department of Civil Engineering, University of Nigeria Nsukka were the soil tests were conducted.

\subsection{Lime}

The lime that was used for the soil stabilization in this research work was quicklime. Its principal sources are rocks, mainly chalk and limestone. The primary chemical composition of these rocks is calcium carbonate, which is then chemically altered to produce the highly caustic material known as quicklime [12].

\subsection{Coconut Husk}

The coconut husk used was the outer part of a coconut usually discarded by consumers or used as tinder for making fire in villages. It was obtained close to the house of a coconut dealer at Onuiyi, Nsukka town in Nsukka local government area. 


\section{METHODOLOGY}

\subsection{Production of Coconut Husk Ash.}

The coconut husk ash used for this work was produced by burning the collected coconut husk in a furnace at the Department of Metallurgical and Materials Engineering, University of Nigeria, Nsukka. The temperature of the furnace was maintained at about $500^{\circ} \mathrm{C}$ and the burning lasted for approximately 8 hours, before the ash was obtained.

\subsection{Experimental Procedure}

In this work, the soil tests were carried out according to the specifications of British Standard (BS) 1377. Preliminary tests were initially carried out on the natural soil sample to obtain its index properties for proper identification of the soil. This includes: Sieve Analysis, Moisture Content, Specific Gravity, Atterberg's Limits and Compaction. Next, the Atterberg's Limits test was repeated again on a mixture of the natural soil and percentages of lime ranging from $2-10 \%$ by weight of the dry soil, after which $4 \%$ lime addition gave the least plasticity index and was used for the compaction and undrained triaxial tests. Then, the undrained triaxial test was conducted to determine the shear strength parameters of the soil. The test was conducted on a mixture of the natural soil with $4 \%$ lime and various percentages of coconut husk ash ranging from $0-12 \%$ by weight of the dry soil, to obtain the shear strength parameters of the soil. Finally, the natural soil was then combined with $4 \%$ lime and percentages of coconut husk ash ranging from $4-20 \%$ by weight of the dry soil at $4 \%$ interval and the compaction test was carried out again using British standard heavy(BSH) and British standard light(BSL) methods.

\subsubsection{Sieve Analysis}

This test was conducted in the laboratory according to the specification in [13], with BS sieve sizes of $25.40 \mathrm{~mm}, 19.05 \mathrm{~mm}, 12.70 \mathrm{~mm}, 9.52 \mathrm{~mm}, 4.75 \mathrm{~mm}$, $2.36 \mathrm{~mm}, 1.18 \mathrm{~mm}, 600 \mu \mathrm{m}, 300 \mu \mathrm{m}, 150 \mu \mathrm{m}$ and a pan. The weight of the materials retained on each sieve size was then recorded and used in the computations for plotting the particle size distribution curve.

\subsubsection{Specific Gravity}

This test was carried out in the laboratory in accordance with the specification in [13], using three density bottles. Three values of specific gravity were obtained using each of the density bottles, and the specific gravity of the natural soil was then determined as the average of the three values.

\subsubsection{Atterberg's Limits}

The liquid limit and plastic limit were determined in the laboratory using the Cassagrande apparatus, and the tests were conducted in accordance with the specification in [13].

\subsubsection{Compaction}

The compaction test was carried out as specified in [14] using different compactive effort namely; BSL and $\mathrm{BSH}$. The difference between the two compactive efforts is that while the soil is compacted in three layers using $2.5 \mathrm{~kg}$ hammer with a $305 \mathrm{~mm}$ height of drop in the BSL compaction method, the soil is compacted in five layers using $4.5 \mathrm{~kg}$ hammer with a $457 \mathrm{~mm}$ height of drop in the BSH compaction method. The test was done to obtain the MDD and optimum moisture content (OMC) for various proportions of the admixtures used.

\subsubsection{Triaxial Test}

The undrained triaxial test was carried out using confining pressures of $69 \mathrm{kN} / \mathrm{m}^{2}, 138 \mathrm{kN} / \mathrm{m}^{2}$ and 276 $\mathrm{kN} / \mathrm{m}^{2}$, in accordance with the specification in [15]. The stress and strain gauge readings were obtained, from which normal and shear stresses were computed for plotting the Mohr's Circle and failure envelope, which gives the angle of internal friction and cohesion of the soil.

\section{RESULTS AND DISCUSSION}

\subsection{Lateritic Soil}

The data in Table1 shows the index properties of the natural soil. From the geotechnical properties of the soil, the lateritic soil can be classified as A-2-6 using the American Association of State Highway and Transportation Officials (AASHTO) soil classification system and as poorly graded sands (SP) using the Unified Soil Classification System (USCS) [16]. Also from the liquid limit and plastic limit obtained, the natural lateritic soil does not possess high clay content and as such is classified as medium plastic based on its plasticity index [16].

\subsection{Atterberg's Limits}

The data in Table3 shows the Atterberg's Limits results for the lime stabilization of the natural soil. Various lime percentages by weight of the dry soil were added to the lateritic soil ranging from $2-10 \%$. The data in the table shows that addition of $4 \%$ lime to the natural soil produced the least plasticity index. This result corresponds to that in the work of [6], who similarly worked on lime stabilization of lateritic soil. 


\subsection{Shear Strength Parameters}

The results of the triaxial test conducted are presented in form of plots in Figures 1 and 2. The intercept and the inverse tangent of the slope of the Mohr's failure envelope were obtained as the soil cohesion and angle of internal friction in the table respectively.

\subsubsection{Cohesion}

The results for the soil cohesion against the natural soil stabilized with 4\%lime and various percentages of $\mathrm{CHA}$ are presented in Figure 1. The trend in Figure 1 shows that the soil cohesion increased gradually on addition of CHA until a peak value of $52 \mathrm{kN} / \mathrm{m}^{2}$ was obtained at $8 \% \mathrm{CHA}$. This gradual increase is probably due to the filling of the large voids in the soil by the fine particles of the CHA and the strong bond formation resulting from the reaction between the lime and the CHA, which properly held the soil mix in well cemented form. A gradual drop was also observed in the magnitude of soil cohesion after the peak value was attained. This drop could be attributed to saturation of the soil mix with excess quantity of CHA, resulting in agglomeration of particles of the CHA due to the presence of weak intermolecular forces of attraction to weaken the soil mix.

This result is also similar to that obtained by [4], and this is as expected since the addition of fine particles of the CHA and lime is likely to increase the fines content of the soil mix, thus leading to the observed increase in the soil cohesion.

\subsubsection{Angle of Internal Friction}

The results for the angle of internal friction against the natural soil stabilized with $4 \%$ lime and various percentages of CHA are presented in Figure 2. The trend observed in Figure 2 is similar to that obtained by [4], except that at $6 \% \mathrm{CHA}$ addition, the angle of internal friction increased. The overall reduction in angle of internal friction could be attributed to the increase in the fines content of the soil mix due to addition of fine particles of CHA and lime. This tends to reduce the intergranular friction between the particles and thus induces slippage of individual particles over another as they rearrange their packing during compaction.

However, the variation obtained at $6 \% \mathrm{CHA}$ addition is probably due to the nature of the bond formation, which altered the angularity of the soil particles such that the intergranular friction and interlocking of the particles improved. This consequently resulted in the increase observed in the angle of internal friction of the soil mix.

Table1: Index Properties of the Natural Lateritic Soil

\begin{tabular}{lll}
\hline S/No & Property & Description \\
\hline 1 & Specific gravity & 2.72 \\
2 & Natural moisture content & $12.5 \%$ \\
3 & Liquid limit & $27.5 \%$ \\
4 & Plastic limit & $14.1 \%$ \\
5 & Plasticity index & $13.4 \%$ \\
6 & Optimum moisture content & $16.5 \%$ \\
7 & (BSL) & $1.51 \mathrm{~g} / \mathrm{cm}^{3}$ \\
8 & Maximum dry density (BSL) & $25 \%$ \\
9 & (BSH) & $1.71 \mathrm{~g} / \mathrm{cm}^{3}$ \\
10 & Maximum dry density (BSH) & $\mathrm{A}-2-6$ \\
11 & ASCHTO classification & $\mathrm{SP}$ \\
12 & Group index & 3 \\
13 & Colour & $\mathrm{Brown}$ \\
14 & Percentage of fines & $91.98 \%$ \\
\hline
\end{tabular}

\subsection{Compaction Result}

The plot of dry density against moisture content for the different percentages of the admixture used are presented in Figures 3 and 4, using BSH and BSL compaction methods respectively.

Table 2: Chemical Composition of the CHA

\begin{tabular}{|c|c|c|c|c|c|}
\hline Oxides & $\mathrm{SiO}_{2}$ & $\mathrm{Al}_{2} \mathrm{O}_{3}$ & $\mathrm{P}_{2} \mathrm{O}_{5}$ & $\mathrm{SO}_{3}$ & $\mathrm{Na}$ \\
\hline $\begin{array}{l}\text { Chemical } \\
\text { composition (\%) }\end{array}$ & 37.00 & 7.74 & 2.62 & 0.79 & 0.2 \\
\hline 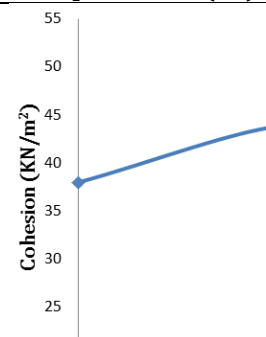 & & & & & \\
\hline 20 & ${ }^{6}$ & $\begin{array}{c}8 \\
C H A+40\end{array}$ & 10 & 12 & \\
\hline
\end{tabular}

Figure 1: Cohesion against Various Percentages of CHA

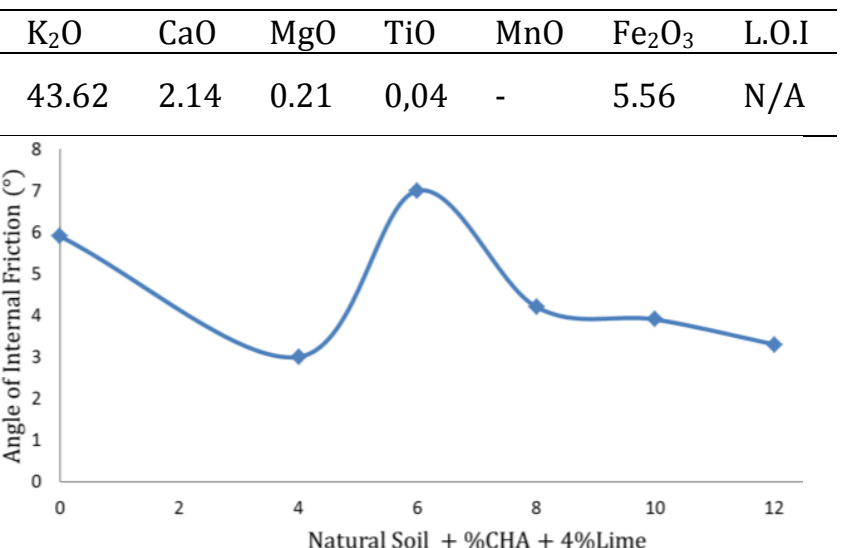

Figure 2: Angle of Internal Friction against Various Percentages of CHA. 
Table 3: Atterberg's Limits Result for Various Percentages of Lime

\begin{tabular}{lllllll}
\hline Lime \% & 0 & 2 & 4 & 6 & 8 & 10 \\
\hline Liquid Limit & 27.5 & 27 & 36.5 & 37.5 & 33 & 32.2 \\
Plastic Limit & 14.1 & 10.2 & 26.4 & 27 & 22.6 & 19.3 \\
$\begin{array}{l}\text { Plasticity } \\
\text { Index }\end{array}$ & 13.4 & 16.8 & 10.1 & 10.5 & 10.4 & 12.9 \\
\hline
\end{tabular}

The value obtained for the MDD of the natural soil seems relatively low in comparison with that obtained by several researchers [8] [10] [17] [18] [19], who have all worked on the stabilization of lateritic soil. The low MDD could have resulted from the fact that the soil is composed of poorly graded sands, indicating presence of large voids. The results of the compaction test carried out shows remarkable improvement in the MDD of the soil using both BSH and BSL methods as in Figure 5. We can see from Figure 5 that as the quantity of CHA was increased, the MDD of the mix increased gradually to rise beyond that of the natural soil sample, until peak values of MDD was obtained for $12 \%$ CHA and 16\% CHA addition for BSH and BSL respectively. From Figures 3 and 4, the MDD of the natural lateritic soil obtained using both BSH and BSL methods are relatively low. This is indicative of presence of large voids present in the natural soil sample. The trend observed in figure 5 could be attributed to the filling of the large voids present in the natural lateritic soil by the fine particles of the CHA and also the replacement of part of the natural lateritic soil with combination of Lime and CHA to produce a higher specific gravity [20], leading to the formation of denser soil mix at higher percentages of CHA addition. The drop in MDD observed after the peak values were obtained is indicative of saturation of the natural lateritic soil with too much quantity of CHA, resulting in agglomeration of particles of the CHA due to the presence of weak intermolecular forces of attraction to produce voids in the soil mix.

Furthermore, the effect of the different compactive effort applied can be seen in the percentage of the CHA required to achieve the peak MDD as shown in Figure 5. The percentage of CHA required to achieve the peak MDD using the BSH was less than that required using the BSL. This is likely to be as a result of the fact that BSH method exerts more energy of impact on the soil mix because of the weight of the hammer and the smaller soil quantity, in each of the layers receiving the impact. Thus, enabling the air voids in the mix to be expelled faster [16].
The observed trend for MDD obtained in this research work is in consonant with that reported by [11] and [20], who investigated the influence of compactive efforts on lateritic soil stabilized with rice husk ash (RHA) and lateritic soil stabilized with a combination cement and RHA respectively. Their results also showed that with more compactive effort, a smaller quantity of the pozzolanic material (CHA) is required to achieve the optimal MDD.

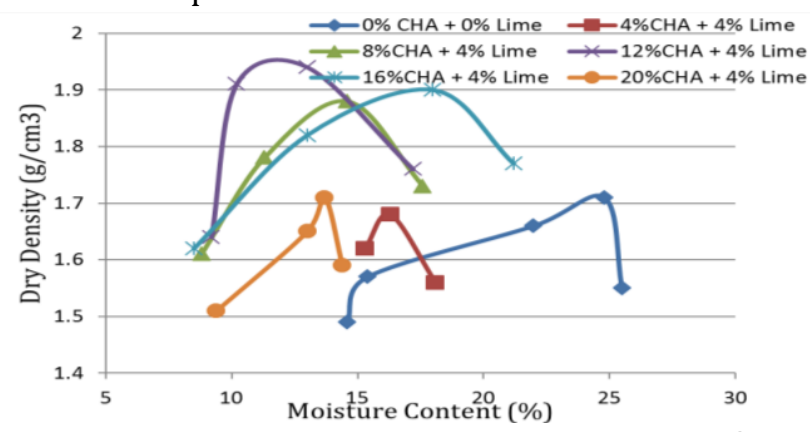

Figure 3: Dry Density against Moisture Content for different percentages of Lime and CHA using BSH

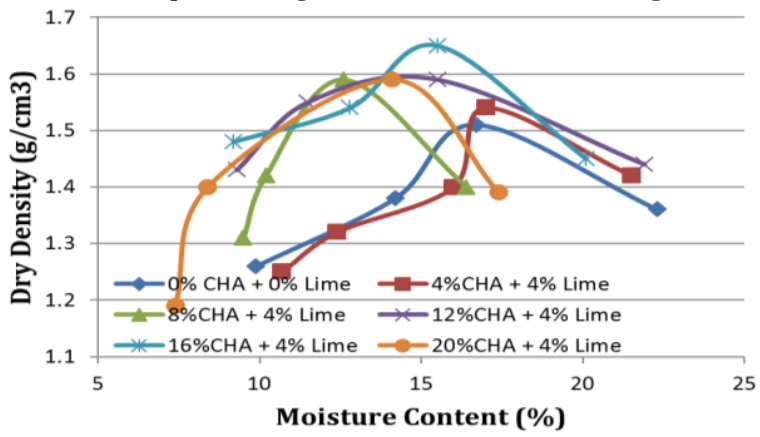

Figure 4: Dry Density against Moisture Content for different percentages of Lime and CHA using BSL

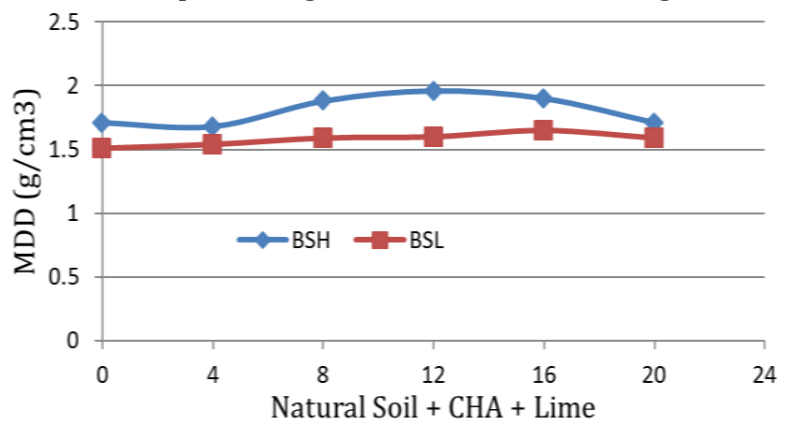

Figure 5: Variation of Maximum Dry Density with percentages of Coconut Husk Ash

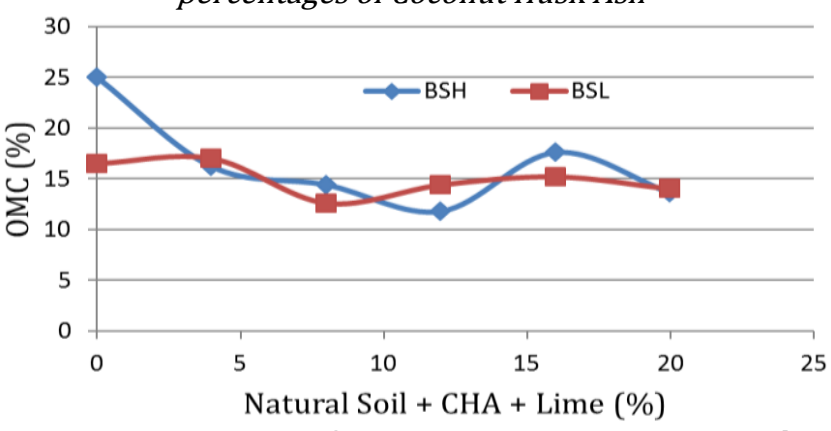

Figure 6: Variation of Optimum Moisture Content with percentages of Coconut Husk Ash

Vol. 36, No. 4, October 2017 


\section{CONCLUSION}

An objective outlook on the shear strength parameters and effectiveness of different compactive effort on lateritic soil stabilized with lime and coconut husk ash has revealed that remarkable improvements in the geotechnical properties of the natural lateritic soil are attainable.

The soil cohesion increased from $38 \mathrm{kN} / \mathrm{m}^{2}$ to $52 \mathrm{KN} / \mathrm{m}^{2}$ with a combination of $4 \%$ lime and $8 \% \mathrm{CHA}$ addition, whereas the angle of internal friction attained a peak angle of $7^{\circ}$ from $5.9^{\circ}$ with a combination of $4 \%$ lime and 6\%CHA. Moreso, the MDD of the natural soil improved tremendously when it was combined with $4 \%$ lime and $12 \%$ CHA using BSH method and $4 \%$ lime and 16\% CHA using BSL method. The MDD of the natural soil was increased from $1.71 \mathrm{~g} / \mathrm{cm}^{3}$ to a peak value of $1.96 \mathrm{~g} / \mathrm{cm}^{3}$ using BSH method and $1.51 \mathrm{~g} / \mathrm{cm}^{3}$ to a peak value of $1.65 \mathrm{~g} / \mathrm{cm}^{3}$ using the BSL method. The result also showed that increasing the compactive effort reduces the quantity of the pozzolanic material (CHA) required for stabilization of the natural lateritic soil to achieve the peak MDD

\section{REFERENCES}

[1] Joel, M. and Edeh, J. E. "Comparative Analysis of Cement and Lime Modification of Ikpayongo Laterite for Effective and Economic Stabilization," Journal of Emerging Trends in Engineering and Applied Sciences, vol. 6, no. 1, pp. 49-56, 2015.

[2] Vaibhav, R. D. and Shrikant, M. H. "Influence of Different Soi Properties on Shear Strength of Soil: A Review," American Journal of Construction and Building Materials, vol. 1, no. 1, pp. 24-27, 2016.

[3] Garber, N. and Hoel, L. Traffic and Highway Engineering, Canada: CENGAGE Learning, 2014.

[4] Adunoye, G. O. "Fines Content and Angle of Internal Friction of a Lateritic Soil: An Experimental Study," American Journal of Engineering Research, vol. 3, no. 3, pp. 16-21, 2014.

[5] Ayininuola, G. M., Agbede, O. A. and Franklin, S. 0. "Influence of Calcium Sulphate on Subsoil Cohesion and Angle of Friction," Journal of Applied Science Research, vol. 5, no. 3, pp. 297304, 2009.

[6] Poulos , S. J. "Liquefaction Related Phenomena," in Advanced Dam Engineering for Design, Janson, R. B. Ed. Van Nostrand Reinhold, , pp. 292-320, 1989.

[7] Sharmer, K. S. Principles, Practice and Design of Highway Engineering (revised edition), New Delhi: S.Chand and Company Ltd, 2012.
[8] Ikeagwuani, C. C., Nwoji C. U. and Okonkwo, C. "Compressibility Characteristics of Lateritic Soil Admixed with Coconut Husk Ash and Lime," International Journal of Engineering Research and Technology, vol. 4, no. II, pp. 31-39, 2015.

[9] Vysakh, P. and Bindu, J. "Stabilisation of Lateritic Soil using Coconut Shell, Leaf and Husk Ash," in Green Technologies, 2012.

[10] Oluremi, J. R., Adedokun, S. I. and Osuolale, O. M. "Stabilizaton of Poor Lateritic Soils with Coconut Husk Ash," International Journal of Engineering Research \& Technology, vol. 1, no. 8, 2012.

[11] Bello, A. A. and Olawale,G. 0. "Influence of Compactive Efforts on Lateritic Soil Stabilized with Rice Husk Ash and Cement," in Proceedings of 11th National Civil Engineering Conference, Port Harcourt, 2013.

[12] Ikeagwuani, C. C. "Compressibility Characteristics of Black Cotton Soil Admixed with Sawdust Ash and Lime," Nigerian Journal of Technology, vol. 35, no. 4, pp. 718-725, 2016.

[13] British Standard Institute, Methods of Testing Soils for Civil Engineering Purposes, BS1377, part 2,1990 .

[14] British Standard Institute, Methods of Testing Soils for Civil Engineering Purposes, BS1377, part4, 1990.

[15] British Standard Institute, Methods of testing soils for civil engineering purposes, BS1377, part 7, 1990.

[16] Murthy, V. S. Principles and Practices of Soil Mechanics and Foundation Engineering, New York: Marcek Decker INC, 2002.

[17] Alhassan, M. "Permeability of Lateritic Soil Treated with Lime and Rice Husk Ash," $A U$ J.T., vol. 12, no. 2, pp. 115-120, 2008.

[18] Joel, M. and Joseph, L. J. "Effect of Compactive Effort on Strength Indices of Laterite Treated with Calcium Carbide Waste," Global Journal of Engineering Research, vol. 14, pp. 47-57, 2015.

[19] Akinwumi, I. I. and Aidomojie, O. I. "Effect of Corncob Ash on the Geotechnical Properties of Lateritic Soil Admixed with Portland Cement" International Journal of Geomatics and Geosciences, vol. 5, no. 3, pp. 375-392, 2015.

[20] Adefemi, B. A., Olufemi, A. S. and Tajudeen, O. A. "Influence of Compactive Efforts on Lateritic Soil Stabilized with Rice Husk Ash" International Journal of Applied Engineering Research, vol. 9, no. 21, pp. 9639-9653, 2014. 